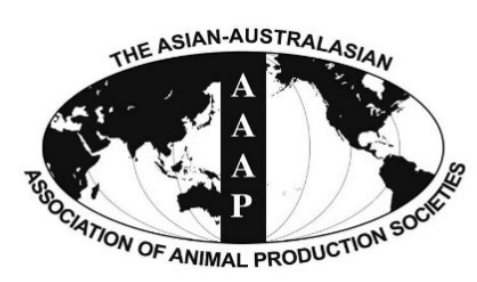

Open Access

Asian Australas. J. Anim. Sci.

Vol. 29, No. 10 : 1416-1423 October 2016

http://dx.doi.org/10.5713/ajas.15.0689

www.ajas.info

pISSN 1011-2367 elSSN 1976-5517

\title{
Effect of Grape Pomace Powder, Mangosteen Peel Powder and Monensin on Nutrient Digestibility, Rumen Fermentation, Nitrogen Balance and Microbial Protein Synthesis in Dairy Steers
}

\author{
S. Foiklang ${ }^{1,2}$, M. Wanapat ${ }^{1, *}$, and T. Norrapoke ${ }^{3}$ \\ ${ }^{1}$ Tropical Feed Resources Research and Development Center (TROFREC), Department of Animal Science, \\ Faculty of Agriculture, Khon Kaen University, Khon Kaen 40002, Thailand
}

\begin{abstract}
This study was designed to investigate the effect of grape pomace powder (GPP), mangosteen peel powder (MPP) and monensin on feed intake, nutrients digestibility, microorganisms, rumen fermentation characteristic, microbial protein synthesis and nitrogen balance in dairy steers. Four, rumen fistulated dairy steers with initial body weight (BW) of $220 \pm 15 \mathrm{~kg}$ were randomly assigned according to a $4 \times 4$ Latin square design to receive four treatments. The treatments were as follows: $\mathrm{T} 1=$ control, $\mathrm{T} 2=$ supplementation with monensin at $33 \mathrm{mg} / \mathrm{kg}$ diet, T3 = supplementation with GPP at $2 \%$ of dry matter intake, and T4 = supplementation with MPP at 30 $\mathrm{g} / \mathrm{kg}$ diet. The steers were offered the concentrate diet at $0.2 \% \mathrm{BW}$ and $3 \%$ urea treated rice straw (UTRS) was fed ad libitum. It was found that GPP supplemented group had higher UTRS intake and nutrient digestibility in terms of neutral detergent fiber and acid detergent fiber than those in control group $(\mathrm{p}<0.05)$. Ammonia nitrogen $\left(\mathrm{NH}_{3}-\mathrm{N}\right)$ and blood urea-nitrogen concentration were higher in monensin, GPP and MPP supplemented groups $(\mathrm{p}<0.05)$. Total volatile fatty acids and propionate in the GPP group were higher than those in the control group $(\mathrm{p}<0.05)$ while acetate concentration, and acetate to propionate ratio were decreased $(\mathrm{p}<0.01)$ when steers were supplemented with GPP, monensin, and MPP, respectively. Moreover, protozoal populations in GPP, MPP, and monensin supplementation were significantly lower than those in the control group $(p<0.05)$, while cellulolytic bacterial population was significantly higher in the control group $(\mathrm{p}<0.05)$. Nitrogen retention, microbial crude protein and efficiency of microbial nitrogen synthesis were found significantly higher in steers that received GPP $(p<0.05)$. Based on this study it could be concluded that the GPP has potential as an alternative feed supplement in concentrate diets which can result in improved rumen fermentation efficiency, digestibility and microbial protein synthesis in steers fed on treated rice straw. (Key Words: Grape Pomace Powder, Mangosteen Peel Powder, Monensin, Microbial Protein Synthesis, Rumen Fermentation, Dairy Steers)
\end{abstract}

\section{INTRODUCTION}

The amount of energy loss as $\mathrm{CH}_{4}$ within ruminant animals may account for $6 \%$ to $10 \%$ of gross energy intake, or $8 \%$ to $14 \%$ of digestible energy intake. So, in targeting methane reduction it is crucial to develop a strategy that

\footnotetext{
* Corresponding Author: M. Wanapat. Tel: +66-43-202368, Fax: +66-43-202368, E-mail: metha@kku.ac.th

${ }^{2}$ Faculty of Animal Science and Technology, Maejo University, Chiangmai 50290, Thailand.

${ }^{3}$ Department of Animal Production Technology, Faculty of AgroIndustrial Technology, Kalasin University, Kalasin 46000, Thailand.

Submitted Aug. 24, 2015; Revised Nov. 26, 2015; Accepted Dec. 24, 2015
}

decreases methane producing micro-biota activities and proliferation without limiting rumen function (Gemeda and Hassen, 2015). Ionophore antibiotics such as monensin are usually used to improve the efficiency of meat and milk production in ruminants. Monensin included in diets decreased $\mathrm{CH}_{4}$ production with short-term decreases in $\mathrm{CH}_{4}$ up to $30 \%$ at a dose level of $33 \mathrm{mg} / \mathrm{kg}$ diet (Guan et al., 2006). However, the use of antibiotics as feed additives has received severe criticism due to their potential health risks for consumers (Jayanegara et al., 2014). Therefore, exploration for natural and safe feed additives that mitigate $\mathrm{CH}_{4}$ emissions while increase productivity of animals simultaneously or at least without hampering the respective productivity is urgently required (Jayanegara et al., 2014). 
Currently, there is increasing interest in exploiting natural products as feed additives to solve problems in animal nutrition and livestock production (Wanapat et al., 2012). Plants containing secondary metabolites, such as condensed tannins (CT) and saponins, have shown a potential to manipulate rumen fermentation by enhancing the efficiency of energy utilization in feed. One of the plants containing secondary metabolites is mangosteen peel (MP) which is a fruit by-product containing high levels of CT as well as saponins which also affects rumen fermentation (Poungchompu et al., 2009). Supplementation with MP and soap berry fruit pellet which are high in CT and saponins have been shown to alter rumen fermentation by lowering the protozoal population and $\mathrm{CH}_{4}$ production (Poungchompu et al., 2009).

Grape pomace (GP) is a high tannin feed by-product produced in large amounts in many parts of the world. The GP is usually discarded as waste and allowed to rot hence posing high environmental pollution and disposal problems in many areas including Thailand (Foiklang et al., 2015). The potential use of this waste in ruminant rations could participate in reducing the shortage of feedstuffs. In the previous study in vitro study by (Foiklang et al., 2015), it was found that supplementation of grape pomace powder (GPP) at $2 \%$ of feed increased in vitro true digestibility while reduced $\mathrm{CH}_{4}$ production. Moreover, Moate et al. (2014) has shown the supplementation $5 \mathrm{~kg}$ of dried grape marc to cattle could reduce gases emissions by $20 \%$ and increased milk production by $5 \%$. However, there are limited studies on comparison of the influences of GPP and other supplements on animal performance, $\mathrm{CH}_{4}$ production and rumen fermentation in dairy steers. Therefore, the aim of this study was to investigate the effect of GPP, monensin and mangosteen peel powder (MPP) on feed intake, nutrient digestibility and rumen fermentation in dairy steers.

\section{MATERIALS AND METHODS}

\section{Animals, diets and experimental design}

Four-rumen fistulated dairy steers with initial body weight (BW) of $220 \pm 15 \mathrm{~kg}$ were randomly assigned according to a $4 \times 4$ latin square design (LSD). The feed ingredients and chemical composition of experimental diets and 3\% urea-treated rice straw (UTRS) are shown in Table 1. All animals were kept in individual pens, mineral blocks and water were available for ad libitum consumption. The concentrate mixed diet was formulated to be at $14 \%$ crude protein $(\mathrm{CP})$. The steers were offered the concentrate diet at $0.2 \%$ BW and 3\% UTRS was fed ad libitum. Four dietary treatments were as follows: $\mathrm{T} 1=$ Control, $\mathrm{T} 2=$ supplementation with monensin at $33 \mathrm{mg} / \mathrm{kg}$ diet, the optimum level from the study of Guan et al. (2006), T3 = supplementation with GPP at $2 \%$ of dry matter intake, the
Table 1. Ingredients and chemical composition of concentrate diet, urea treated rice straw and feed supplements used in the experiment

\begin{tabular}{|c|c|c|c|c|}
\hline Item & Concentrate & UTRS & GPP & MPP \\
\hline \multicolumn{5}{|l|}{ Ingredient (g/kg DM) } \\
\hline Cassava chip & 636 & - & - & - \\
\hline Rice bran & 100 & - & - & - \\
\hline Coconut meal & 118 & - & - & - \\
\hline Palm kernel meal & 71 & - & - & - \\
\hline Urea & 30 & - & - & - \\
\hline Molasses & 20 & - & - & - \\
\hline Mineral premix ${ }^{1}$ & 10 & - & - & - \\
\hline Salt & 10 & - & - & - \\
\hline Sulfur & 5 & - & - & - \\
\hline \multicolumn{5}{|l|}{ Chemical composition } \\
\hline Dry matter (DM, g/kg) & 892 & 506 & 895 & 931 \\
\hline Organic matter $(\mathrm{g} / \mathrm{kg} \mathrm{DM})$ & 922 & 861 & 842 & 963 \\
\hline Crude protein (g/kg DM) & 142 & 55 & 128 & 153 \\
\hline $\begin{array}{l}\text { Neutral detergent fiber } \\
(\mathrm{g} / \mathrm{kg} \mathrm{DM})\end{array}$ & 183 & 723 & 475 & 606 \\
\hline $\begin{array}{l}\text { Acid detergent fiber } \\
(\mathrm{g} / \mathrm{kg} \mathrm{DM})\end{array}$ & 152 & 575 & 306 & 559 \\
\hline $\begin{array}{l}\text { Condensed tannins } \\
(\mathrm{g} / \mathrm{kg} \mathrm{DM})\end{array}$ & - & - & 123 & 177 \\
\hline $\begin{array}{l}\text { Crude saponins } \\
\text { (g/kg DM) }\end{array}$ & - & - & 146 & - \\
\hline
\end{tabular}

UTRS, 3\% urea treated rice straw; GPP, grape pomace powder; MPP, mangosteen peel powder; DM, dry matter.

${ }^{1}$ Minerals and vitamins (each $\mathrm{kg}$ contains): Vitamin A, 10,000,000 IU; Vitamin E, 70,000 IU; Vitamin D, 1,600,000 IU; Fe, 50 g; Zn, 40 g; Mn, $40 \mathrm{~g} ; \mathrm{Co}, 0.1 \mathrm{~g} ; \mathrm{Cu}, 10 \mathrm{~g}$; Se, $0.1 \mathrm{~g} ; \mathrm{I}, 0.5 \mathrm{~g}$.

optimum level from the previous study of Foiklang et al. (2015), and T4 = supplementation with MPP at $30 \mathrm{~g} / \mathrm{kg}$ diet, the optimum level from the research of Pilajun and Wanapat. (2013). The experiment was conducted for four periods, and each period lasted 21 days. During the first 14 days, all animals were fed with their respective diets, whereas during the last 7 day, they were moved to metabolism crates for total collection of urine and feces.

\section{Data collection, analysis and sampling procedures}

At the end of each period, rumen fluid, and digesta were collected at $0,2,4$, and 6 h-post feeding. Approximately $200 \mathrm{~mL}$ of rumen fluid was taken from the middle part of the rumen using a $60 \mathrm{~mL}$ hand syringe at $0,2,4$, and $6 \mathrm{~h}$ post feeding. Ruminal temperature and $\mathrm{pH}$ were measured immediately using a portable $\mathrm{pH}$ and temperature meter (Hanna Instruments HI 8424 microcomputer, Singapore, Singapore). Rumen fluid samples were then filtered through four layers of cheesecloth. Samples were divided into three portions, the first portion was centrifuged at $16,000 \times g$ for $15 \mathrm{~min}$, and the supernatant was stored at $-20^{\circ} \mathrm{C}$ before $\mathrm{NH}_{3}-\mathrm{N}$ analysis using the micro-Kjeldahl methods (AOAC, 
1998) and volatile fatty acids (VFA) analysis using high pressure liquid chromatography (HPLC, Instruments by controller water model $600 \mathrm{E}$; water model $484 \mathrm{UV}$ detector; column novapak $\mathrm{C} 18$; column size $3.9 \mathrm{~mm} \times 300 \mathrm{~mm}$; mobile phase $10 \mathrm{mM} \mathrm{H}_{2} \mathrm{PO}_{4}$ [pH 2.5]) according to Samuel et al. (1997). The second portion was fixed with $10 \%$ formalin solution $(1: 9 \mathrm{v} / \mathrm{v}$, rumen fluid: $10 \%$ formalin) for measuring microbial populations by total direct count of bacteria, protozoa and fungi using methods of Galyean (1989) with a hemocytometer (Boeco, Hamburg, Germany). The last portion was cultured using a roll-tube technique (Hungate, 1969) to identify bacterial groups (cellulolytic, proteolytic, amylolytic and total viable count bacteria).

Feces were collected and weighed during the last 7 days of each period by total collection sampling. The fecal samples were collected about $5 \%$ of total fresh weight and divided into 2 parts; first part for dry matter (DM) analysis every day and second part were kept in refrigerator and pooled by cattle at the end of each period for later chemical analysis. After being dried at $50^{\circ} \mathrm{C}$ for $48 \mathrm{~h}$, samples were ground to pass through a $1 \mathrm{~mm}$ sieve in the feed mill using Cyclotech Mill, Tecator, Hoganas, Sweden for chemical analysis. The samples were chemically analyzed (AOAC, 1998) for DM, crude ash and CP. Neutral detergent fiber (NDF) and acid detergent fiber (ADF) in samples were estimated according to Van Soest et al. (1991). Contents of CT in GPP were analyzed by using the modified vanillin$\mathrm{HCl}$ method, while crude saponins (CS) were measured by using methanol extraction modified by Poungchompu et al. (2009). The GP containing grape pulps and seeds were obtained from wine production factories of PB Valley Khao Yai Winery, Thailand. Total urine was collected on the same days with feces by using plastic container within drop of sulfuric acid $(10 \%)$ to protect nitrogen loss. The urinary samples were collected about $10 \%$ of volume urine samples and kept in refrigerator and pooled at the end of period to be analyzed for total $\mathrm{N}$ (AOAC, 1998) to determine $\mathrm{N}$ utilization.

Blood samples (about $10 \mathrm{~mL}$ ) were drawn from the jugular vein at the same time as rumen fluid sampling and kept into the tubes which ethylenediaminetetraacetic acid was added. Blood samples were then placed on the ice and transported to the laboratory for separating plasma from the whole blood. Samples were refrigerated for $1 \mathrm{~h}$ and then centrifuged at 3,500 $\times \mathrm{g}$ for $20 \mathrm{~min}$ (Table Top Centrifuge PLC-02, IA, USA). The plasma was removed and stored at $-20^{\circ} \mathrm{C}$ for analysis of blood urea-nitrogen (BUN) according to Crocker (1967). The allantoin in the urine was determined by HPLC. The amount of microbial purines derivative (PD) absorption (X mmol/d) corresponding to the $\mathrm{PD}$ excretion ( $\mathrm{Y} \mathrm{mmol} / \mathrm{d})$ was calculated basing on the relationship derived by Chen and Gomes (1995): $\mathrm{Y}=$ $0.85 \mathrm{X}+\left(0.385 \mathrm{~W}^{0.75}\right)$. The microbial $\mathrm{N}$ supply (MNS) was estimated by urinary excretion of PD according to Chen and Gomes (1995): MNS $(\mathrm{g} / \mathrm{d})=70 \mathrm{X} /(0.116 \times 0.83 \times 1,000)=$ $0.727 \mathrm{X}$; where $\mathrm{X}$ is PD absorption in $\mathrm{mmol} / \mathrm{d}$, digestibility of microbial purine is 0.83 , the $\mathrm{N}$ content of purines is 70 $\mathrm{mg} \mathrm{N} / \mathrm{mmol}$, and the ratio of purine- $\mathrm{N}$ : total $\mathrm{N}$ in mixed rumen microbes is 11.6:100. The efficiency of microbial $\mathrm{N}$ synthesis (EMNS) to denote the microbial $\mathrm{N}$ supplied to the animal per unit of digestible organic matter apparently fermented in the rumen (DOMR) was calculated using the following formula: EMNS $=M N(\mathrm{~g} / \mathrm{d}) / \mathrm{DOMR}$ (assuming that rumen digestion was $650 \mathrm{~g} / \mathrm{kg}$ organic matter (OM) of digestion in total tract, $\mathrm{DOMR}=\mathrm{DOMI} \times 0.65 ; \mathrm{DOMI}=$ digestible organic matter intake).

\section{Statistical analysis}

Statistical analysis was performed using the general linear model procedure of SAS (1998). Data were analyzed using the model $\mathrm{Y}_{\mathrm{ijk}}=\mu+\mathrm{M}_{\mathrm{i}}+\mathrm{A}_{\mathrm{j}}+\mathrm{P}_{\mathrm{k}}+\varepsilon_{\mathrm{ijk}}$, where $\mathrm{Y}_{\mathrm{ijk}}=$ observation from animal $j$, receiving diet $i$, in period $k ; \mu=$ the overall of mean; $\mathrm{M}_{\mathrm{i}}=$ the mean effect of treatment $(i=1$, $2,3,4) ; A_{j}=$ the effect of animal $(j=1,2,3,4) ; P_{k}=$ the effect of period $(k=1,2,3,4)$; and $\varepsilon_{\mathrm{ijk}}=$ the residual error. Treatment means were statistically compared by Duncan's New Multiple Range Test. Differences among means with $p<0.05$ were accepted as representing statistically significant differences.

\section{RESULTS AND DISCUSSION}

\section{Chemical composition of feeds}

The experimental feeds and their chemical compositions are shown in Table 1. The mixture of concentrate diet contained CP $142 \mathrm{~g} / \mathrm{kg}$ DM. Concentrate ingredients were based on local resources, consisting of cassava chip, rice bran, coconut meal and palm kernel meal which had a higher quality in term of $\mathrm{CP}$ and also low in fiber. This concentrate was well consumed by animals during the experimental periods. GPP contained CP, CT, CS, NDF, and $\mathrm{ADF}$ at $128,123,146,475$, and $306 \mathrm{~g} / \mathrm{kg}$ DM while MPP contained CP, CT, NDF, and ADF at 153, 177, 606, and 559 $\mathrm{g} / \mathrm{kg}$ DM, respectively. The CP content of GPP is within the range (110 to $130 \mathrm{~g} / \mathrm{kg} \mathrm{DM}$ ) reported by $\mathrm{Yu}$ and Ahmedna (2013). The total protein content of grape seed protein may vary significantly depending on the variety of grape, location and fertilization conditions (Yu and Ahmedna, 2013). The CT content in GPP was higher than the value reported by Moate et al. (2014). Moreover, the CT value in MPP (177 g/kg DM) was slightly higher than other values reported which ranged from 70 to $168 \mathrm{~g} / \mathrm{kg}$ DM (Norrapoke et al., 2014). The inclusion of the GP into livestock rations provides an opportunity not only to use a waste by-product resourcefully, but also to induce beneficial metabolic changes in animals. The UTRS contained CP, NDF, and 
$\mathrm{ADF}$ at 55,723 , and $575 \mathrm{~g} / \mathrm{kg} \mathrm{DM}$ and was similar to that reported earlier by Anantasook et al. (2014) and Foiklang et al. (2015).

\section{Feed intake and digestibility}

Table 2 shows data on feed intake, nutrient intakes and digestibility of nutrients. Under the current study, it was found that GPP supplemented group had higher UTRS intake than those in other groups $(p<0.05)$ in terms of percentage of $\mathrm{BW}$ and $\mathrm{g} / \mathrm{kg} \mathrm{BW}^{0.75}$. However, total dry matter intake was not significantly different among treatments $(\mathrm{p}>0.05)$. As observed during the experiment, both non-supplemented and supplemented animals well consumed the diet. Pilajun and Wanapat (2013) also found that adding $3 \%$ of MP (CT at $164 \mathrm{~g} / \mathrm{kg} \mathrm{DM})$ to the buffaloes diet had no effect on feed intake. It was also found that $\mathrm{OM}$, NDF, and ADF intakes were significantly higher when steers were fed with GPP $(p<0.05)$ while CP intake was

Table 2. Effect of grape pomace powder (GPP), mangosteen peel powder (MPP) and monensin on feed intake, nutrient intakes, and digestibilities in dairy steers

\begin{tabular}{|c|c|c|c|c|c|}
\hline Items & Control & Monensin & GPP & MPP & SEM \\
\hline \multicolumn{6}{|l|}{ Concentrate intake } \\
\hline $\mathrm{kg} / \mathrm{d}$ & 0.59 & 0.65 & 0.63 & 0.62 & 0.05 \\
\hline$\%$ of BW & 0.26 & 0.28 & 0.28 & 0.26 & 0.01 \\
\hline $\mathrm{g} / \mathrm{kg} \mathrm{BW}^{0.75}$ & 10.2 & 10.8 & 11.0 & 10.3 & 0.17 \\
\hline \multicolumn{6}{|l|}{ UTRS intake } \\
\hline $\mathrm{kg} / \mathrm{d}$ & $4.56^{\mathrm{b}}$ & $4.61^{\mathrm{b}}$ & $4.81^{\mathrm{a}}$ & $4.78^{\mathrm{ab}}$ & 0.07 \\
\hline$\%$ of BW & $2.07^{\mathrm{c}}$ & $2.09^{\mathrm{bc}}$ & $2.15^{\mathrm{a}}$ & $2.12^{\mathrm{a}}$ & 0.03 \\
\hline $\mathrm{g} / \mathrm{kg} \mathrm{BW}^{0.75}$ & $79.8^{\mathrm{c}}$ & $80.7^{\mathrm{bc}}$ & $85.3^{\mathrm{a}}$ & $83.7^{\mathrm{b}}$ & 1.04 \\
\hline \multicolumn{6}{|l|}{ Supplements } \\
\hline $\mathrm{kg} / \mathrm{d}$ & $0.00^{\mathrm{c}}$ & $0.033^{\mathrm{b}}$ & $0.11^{\mathrm{a}}$ & $0.03^{b}$ & 0.02 \\
\hline$\%$ of BW & $0.00^{\mathrm{b}}$ & $0.01^{\mathrm{b}}$ & $0.05^{\mathrm{a}}$ & $0.01^{\mathrm{b}}$ & 0.01 \\
\hline $\mathrm{g} / \mathrm{kg} \mathrm{BW}^{0.75}$ & $0.00^{\mathrm{b}}$ & $0.58^{\mathrm{b}}$ & $2.10^{\mathrm{a}}$ & $0.53^{\mathrm{b}}$ & 0.45 \\
\hline \multicolumn{6}{|l|}{ Total intake } \\
\hline $\mathrm{kg} / \mathrm{d}$ & 5.2 & 5.3 & 5.6 & 5.4 & 0.14 \\
\hline$\%$ of BW & 2.3 & 2.4 & 2.5 & 2.5 & 0.03 \\
\hline $\mathrm{g} / \mathrm{kg} \mathrm{BW}^{0.75}$ & 90.0 & 92.1 & 98.4 & 94.5 & 2.23 \\
\hline \multicolumn{6}{|l|}{ Nutrient intake $(\mathrm{kg} / \mathrm{h} / \mathrm{d})$} \\
\hline Organic matter & $4.5^{\mathrm{b}}$ & $4.5^{\mathrm{b}}$ & $4.8^{\mathrm{a}}$ & $4.7^{\mathrm{ab}}$ & 0.08 \\
\hline Crude protein & 0.3 & 0.3 & 0.4 & 0.3 & 0.01 \\
\hline Neutral detergent fiber & $3.4^{\mathrm{b}}$ & $3.4^{\mathrm{b}}$ & $3.7^{\mathrm{a}}$ & $3.6^{\mathrm{ab}}$ & 0.06 \\
\hline Acid detergent fiber & $2.7^{\mathrm{b}}$ & $2.7^{\mathrm{b}}$ & $2.9^{\mathrm{a}}$ & $2.8^{\mathrm{ab}}$ & 0.05 \\
\hline \multicolumn{6}{|l|}{ Nutrient digestibility (\%) } \\
\hline Dry matter & 62.4 & 62.2 & 62.5 & 63.6 & 2.21 \\
\hline Organic matter & 66.6 & 64.0 & 66.5 & 70.5 & 1.49 \\
\hline Crude protein & 67.5 & 68.8 & 72.5 & 74.8 & 2.20 \\
\hline Neutral detergent fiber & $52.5^{\mathrm{b}}$ & $61.7^{\mathrm{a}}$ & $62.2^{\mathrm{a}}$ & $60.4^{\mathrm{ab}}$ & 0.56 \\
\hline Acid detergent fiber & $44.8^{\mathrm{b}}$ & $49.1^{\mathrm{ab}}$ & $53.3^{\mathrm{a}}$ & $48.7^{\mathrm{ab}}$ & 0.71 \\
\hline
\end{tabular}

SEM, standard error of the means; BW, body weight; UTRS, urea treated rice straw.

abc Values within the row with different superscripts are significantly different $(\mathrm{p}<0.05)$ similar among treatments $(\mathrm{p}>0.05)$.

In addition, nutrient digestibility in terms of NDF and ADF in GPP supplemented group were significantly higher than those in control group $(\mathrm{p}<0.05)$. It could be due to CT in the optimal level (20 to $40 \mathrm{~g} / \mathrm{kg} \mathrm{DM}$ ) could improve nutrient digestibility (Markar, 2003) which lead to increase voluntary feed intake. However, other authors have found that feeding high levels of dietary saponins and/or tannins decreased apparent digestibility (Poungchompu et al., 2009; Bhatta et al., 2012). The negative effect of tannins on fermentation and digestion could be related to the formation of tannin-carbohydrate and tannin-protein complexes that are less degradable or toxic to rumen microbes. However, Gemeda and Hassen (2015) stated that the decreasing in fermentation and digestibility by CT levels might be due to their continuous effect during fermentation and digestibility.

\section{Rumen fermentation parameters and blood metabolites}

Measured rumen variables included temperature, $\mathrm{pH}$, $\mathrm{NH}_{3}-\mathrm{N}$, and VFA. Plasma urea $\mathrm{N}$ was also determined to investigate the relationship with rumen $\mathrm{NH}_{3}-\mathrm{N}$ and protein utilization. The pattern of ruminal fermentation and overall means are presented in Table 3. Ruminal temperature and ruminal $\mathrm{pH}$ were similar among treatments $(\mathrm{p}>0.05)$ while $\mathrm{NH}_{3}-\mathrm{N}$ and BUN concentration were higher in monensin, GPP and MPP supplemented group $(\mathrm{p}=0.07)$. Ruminal $\mathrm{pH}$ and temperature were stable at $\mathrm{pH} 6.6$ to 6.7 and temperature of $38.7^{\circ} \mathrm{C}$ to $39.1{ }^{\circ} \mathrm{C}$, and the $\mathrm{pH}$ was within the range considered optimal for microbial digestion of fiber and protein (Wanapat, 1990). In current study, ruminal $\mathrm{NH}_{3}-$ $\mathrm{N}$ concentrations were 7.7 to $11.8 \mathrm{mg} / \mathrm{dL}$ and were close to those previously reported by Wanapat and Pimpa (1999) for

Table 3. Effect of grape pomace powder (GPP), mangosteen peel powder (MPP) and monensin on rumen fermentation characteristic in dairy steers

\begin{tabular}{lccccc}
\hline Items & Control & Monensin & GPP & MPP & SEM \\
\hline Ruminal pH & 6.64 & 6.61 & 6.67 & 6.70 & 0.04 \\
Temperature $\left({ }^{\circ} \mathrm{C}\right)$ & 38.9 & 38.7 & 39.1 & 38.8 & 0.03 \\
$\mathrm{NH}_{3}-\mathrm{N}(\mathrm{mg} / \mathrm{dL})$ & $7.7^{\mathrm{b}}$ & $11.8^{\mathrm{a}}$ & $10.2^{\mathrm{a}}$ & $9.8^{\mathrm{a}}$ & 0.77 \\
$\mathrm{BUN}(\mathrm{mg} / \mathrm{dL})$ & $7.2^{\mathrm{b}}$ & $9.2^{\mathrm{a}}$ & $8.5^{\mathrm{a}}$ & $8.3^{\mathrm{ab}}$ & 0.35 \\
Total VFA (mmol/L) & $109.1^{\mathrm{b}}$ & $112.9^{\mathrm{ab}}$ & $115.5^{\mathrm{a}}$ & $113.1^{\mathrm{ab}}$ & 1.03 \\
mol/100 mol total VFA & & & & & \\
$\quad$ Acetic acid, C2 & $70.4^{\mathrm{a}}$ & $65.4^{\mathrm{bc}}$ & $62.6^{\mathrm{c}}$ & $66.5^{\mathrm{b}}$ & 0.49 \\
$\quad$ Propionic acid, C3 & $19.1^{\mathrm{c}}$ & $22.9^{\mathrm{b}}$ & $26.0^{\mathrm{a}}$ & $22.6^{\mathrm{b}}$ & 0.32 \\
$\quad$ Butyric acid, C4 & 10.5 & 11.7 & 11.4 & 10.9 & 0.48 \\
$\mathrm{C} 2 / \mathrm{C} 3$ ratio & $3.6^{\mathrm{a}}$ & $2.9^{\mathrm{b}}$ & $2.4^{\mathrm{c}}$ & $2.9^{\mathrm{b}}$ & 0.05 \\
$\mathrm{C} 2+\mathrm{C} 4 / \mathrm{C} 3$ & $4.2^{\mathrm{a}}$ & $3.4^{\mathrm{ab}}$ & $2.8^{\mathrm{b}}$ & $3.4^{\mathrm{ab}}$ & 0.29 \\
$\mathrm{CH}_{4}$ production & $33.4^{\mathrm{a}}$ & $31.4^{\mathrm{ab}}$ & $29.5^{\mathrm{b}}$ & $31.7^{\mathrm{ab}}$ & 0.79 \\
\hline
\end{tabular}

SEM, standard error of the means; BUN, blood urea-nitrogen; VFA, volatile fatty acids.

${ }^{1}$ Calculated $\mathrm{CH}_{4}$ production $(\mathrm{mol} / 100 \mathrm{~mol}$ TVFA $)=0.45(\% \mathrm{C} 2)-0.275$ $(\% \mathrm{C} 3)+0.40(\% \mathrm{C} 4)$.

abc Values within the row with different superscripts are significantly different $(\mathrm{p}<0.05)$. 
improving rumen ecology, microbial protein synthesis, digestibility and voluntary feed intake. Increasing ruminal $\mathrm{NH}_{3}-\mathrm{N}$ concentrations also resulted in increasing concentrations of BUN. Concentrations of BUN are highly correlated to the concentration of $\mathrm{NH}_{3}$ production in the rumen and BUN concentration was influenced by treatments and the values were ranged from 7.2 to 9.2 $\mathrm{mg} / \mathrm{dL}$. Actually, monensin could reduce the $\mathrm{NH}_{3}-\mathrm{N}$ concentration in the rumen by decreasing the peptide and amino acid degradation as monensin inhibits growth of hyper-ammonia producing bacteria. However, some grampositive bacteria may be resistant to monensin which was also observed by Krause and Russell (1996) who found no effects of monensin on Clostridium aminphilum which is a gram-positive bacterium that contributes to amino acid degradation in the rumen.

There were differences in total VFA and VFA profiles (Table 3) when steers received monensin, GPP and MPP supplementation. Total VFA was higher in GPP supplemented group $(\mathrm{p}<0.05)$ while propionic acid concentrations was higher and acetic acid and acetic to propionic ratio were lower in the supplemented group than those in the control group especially in the GPP supplemented group $(\mathrm{p}<0.05)$ while the concentration of butyric acid was not affected by the supplements. Earlier work reported that $\mathrm{CT}$ and saponins had a variable effect on ruminal VFA concentration (Anantasook et al., 2014; Norrapoke et al., 2014). The effect of CT in GPP and MPP on promoting VFA concentration was very clear when animal were fed a high roughage diet. A similar shift in total VFA and propionic acid production by MP has been reported by Piajun and Wanapat (2013). The expected shift in the VFA profile from acetic to propionic was associated with shift of hydrogen from the methane pathway making it available to be used in producing propionic acid. Since fiber-degrading microorganisms are related to higher acetate production, inhibition of the cellulolytic bacteria and the anaerobic fungi species leads to lower acetate to propionate ratio (Jayanegara et al., 2014). However, the earlier work by Moate et al. (2014) stated that dried and ensiled grape marc in dairy cows diets could decrease acetic acid concentration. Calculated $\mathrm{CH}_{4}$ production was significantly lower when GPP was supplemented $(\mathrm{p}<0.05)$. Many previous studies reported that CT and saponins containing plants and their extracts appeared to be useful in suppressing methane release (Moate et al., 2014). It is clear that tannins had suppressed $\mathrm{CH}_{4}$ production irrespective of digestion and pattern of VFA production (Gemeda and Hassen, 2015). Monensin also is a widely used feed additive with the potential to minimize $\mathrm{CH}_{4}$ emissions from ruminants (Appuhamy et al., 2013). However, there was no reduction of $\mathrm{CH}_{4}$ production by monensin supplement in current study.

In the previous experiment, Moate et al. (2014) reported a $20 \%$ decrease in $\mathrm{CH}_{4}$ emissions and a $23 \%$ decrease in $\mathrm{CH}_{4}$ yield when either dried or ensiled grape marc was fed to dairy cows. This could be due to at least 4 substances, fat, lignin, tannins, and dl-tartaric acid, contained in GP that theoretically could be partly responsible for the observed effects. Moreover, MPP and GPP contained saponins which could decrease $\mathrm{CH}_{4}$ production.

\section{Rumen microorganisms}

Table 4 presents the rumen microorganism population data. Bacterial population and fungal zoospores were similar among treatment $(\mathrm{p}>0.05)$. Meanwhile, protozoal populations in GPP, MPP, and monensin supplementation were significantly lower than those in control group $(p<0.05)$. It is possible that CT contained in GPP and MPP may play an important role in decreasing protozoal population. Consequently, rumen methanogenic bacteria could be reduced as they adhered with each other. Similarly, this data was in accordance with previous report of Norrapoke et al. (2014). The cellulolytic bacterial population was significantly lower in the supplemented groups $(p<0.05)$ while total viable bacteria, amylolytic bacteria and proteolytic bacteria population were unchanged $(\mathrm{p}>0.05)$. As the data have shown that NDF digestibility of

Table 4. Effect of grape pomace powder (GPP), mangosteen peel powder (MPP) and monensin on ruminal microorganisms in dairy steers

\begin{tabular}{|c|c|c|c|c|c|}
\hline Items & Control & Monensin & GPP & MPP & SEM \\
\hline \multicolumn{6}{|l|}{ Ruminal microbes (cell/mL) } \\
\hline Bacteria $\left(\times 10^{10}\right)$ & 3.4 & 3.0 & 3.2 & 3.0 & 0.14 \\
\hline Protozoa $\left(\times 10^{6}\right)$ & $3.2^{\mathrm{a}}$ & $2.6^{\mathrm{b}}$ & $2.7^{\mathrm{b}}$ & $2.4^{\mathrm{c}}$ & 0.06 \\
\hline Fungal zoospores $\left(\times 10^{6}\right)$ & 1.1 & 1.2 & 1.3 & 1.1 & 0.06 \\
\hline \multicolumn{6}{|l|}{ Variable bacteria $(\mathrm{CFU} / \mathrm{mL})$} \\
\hline Total viable bacteria $\left(\times 10^{10}\right)$ & 1.0 & 1.3 & 1.4 & 1.3 & 0.27 \\
\hline Cellulolytic bacteria $\left(\times 10^{8}\right)$ & $4.9^{\mathrm{a}}$ & $3.8^{\mathrm{b}}$ & $3.2^{\mathrm{b}}$ & $2.7^{\mathrm{b}}$ & 0.29 \\
\hline Amylolytic bacteria $\left(\times 10^{7}\right)$ & 3.3 & 2.7 & 3.6 & 3.8 & 2.68 \\
\hline Proteolytic bacteria $\left(\times 10^{7}\right)$ & 1.3 & 1.4 & 1.5 & 1.5 & 0.17 \\
\hline
\end{tabular}

SEM, standard error of the means.

${ }^{a b c}$ Values within the row with different superscripts are significantly different $(p<0.05)$. 
monensin and NDF/ADF digestibility of GPP supplementation were improved while cellulolytic bacteria were decreased. It could be due to another group of microbes that can play an important role in degradation of plant cell walls, namely fungi (Lee et al., 2000). Although the rumen bacteria are believed to be responsible for most of the feed digestion in the rumen because of their numerical predominance and metabolic diversity, the results obtained from Lee et al. (2000) suggested that the contribution of the fungal fraction to cell wall degradation may greatly exceed that of the bacteria. Moreover, the carboxymethyl cellulase activities of the culture supernatants for the fungi systems was also higher than that for the bacteria and protozoa monoculture systems. However, current study didn't measured fibrolytic or cellulolytic enzymes activities. On the other hand, the number of fungal zoospores was decreased by soapberry fruit-MP pellet supplementation in dairy heifers (Poungchompu et al., 2009). The groups with GPP supplementation showed the significantly lower protozoal population than non-supplemented group. Ruminal protozoa counts were reduced through the addition of GPP and MPP in agreement with the previous work (Pilajan and Wanapat, 2013; Moate et al., 2014; Norrapoke et al., 2014). It is possible that CT contained in GPP and MPP may play an important role in decreasing protozoal population. Accordingly, protozoa provide hydrogen as a substrate for methanogenesis conducted by the methanogens. Therefore, a reduction in protozoa population (defaunation) may lead to a decrease in methanogen population and, subsequently, $\mathrm{CH}_{4}$ emission as well (Jayanegara et al., 2014). When the protozoa population is reduced in the presence of saponinrich sources, acetate is concomitantly reduced since it is a product of protozoa metabolism from the fermentation of sugar. Further, methanogens associated with protozoa are decreased, and hence the electron transfer reaction has to search for an alternative pathway in which propionate (an alternative hydrogen sink) formation is stimulated (McAllister and Newbold, 2008).

\section{Nitrogen utilization and purine derivatives}

Effect of GPP, MPP, and monensin on nitrogen balance, purine derivatives and microbial CP supply in dairy steers are presented in Table 5. Total $\mathrm{N}$ intake, fecal $\mathrm{N}$, urinary $\mathrm{N}$ and $\mathrm{N}$ absorption were similar among treatments $(\mathrm{p}>0.05)$. Meanwhile, steers received GPP and MPP showed the higher levels of $\mathrm{N}$ retention (32.4 and $32.2 \mathrm{~g} / \mathrm{d}$; respectively; $\mathrm{p}<0.05$ ) and the lowest was in non-supplemented group $(28.1 \mathrm{~g} / \mathrm{d})$. As previously reported by McSweeney et al. (2001) that CT improved rumen ecology especially enhancing microbial protein synthesis. Normally, when protein degradation is more rapid than synthesis, $\mathrm{NH}_{3}$ will accumulate in the rumen liquor and is absorbed into the
Table 5. Effect of grape pomace powder (GPP), mangosteen peel powder (MPP) and monensin on nitrogen balance, excretion of urinary purine derivatives (PD) and microbial crude protein supply in dairy steers

\begin{tabular}{|c|c|c|c|c|c|}
\hline Items & Control & Monensin & GPP & MPP & SEM \\
\hline \multicolumn{6}{|l|}{$\mathrm{N}$ balance $(\mathrm{g} / \mathrm{d})$} \\
\hline $\mathrm{N}$ intake & 62.6 & 64.1 & 65.9 & 65.0 & 1.37 \\
\hline Fecal N & 14.2 & 13.8 & 14.1 & 14.0 & 0.27 \\
\hline Urinary $\mathrm{N}$ & 20.3 & 19.1 & 19.4 & 18.8 & 0.98 \\
\hline $\mathrm{N}$ absorption & 48.4 & 50.3 & 51.8 & 51.0 & 2.11 \\
\hline $\mathrm{N}$ retention & $28.1^{\mathrm{a}}$ & $31.2^{\mathrm{ab}}$ & $32.4^{\mathrm{b}}$ & $32.2^{\mathrm{b}}$ & 1.69 \\
\hline \multicolumn{6}{|l|}{$\mathrm{PD}(\mathrm{mmol} / \mathrm{d})$} \\
\hline $\begin{array}{l}\text { Allantoin } \\
\text { excretion }\end{array}$ & $77.3^{\mathrm{a}}$ & $82.2^{\mathrm{ab}}$ & $88.4^{\mathrm{b}}$ & $86.8^{\mathrm{b}}$ & 2.79 \\
\hline $\begin{array}{l}\text { Allantoin } \\
\text { absorption }\end{array}$ & $66.4^{\mathrm{a}}$ & $72.3^{\mathrm{ab}}$ & $79.8^{\mathrm{b}}$ & $77.8^{\mathrm{b}}$ & 3.22 \\
\hline MNS (g/d) & $48.3^{\mathrm{a}}$ & $52.6^{\mathrm{ab}}$ & $58.0^{\mathrm{b}}$ & $56.5^{\mathrm{ab}}$ & 2.34 \\
\hline $\mathrm{MCP}(\mathrm{g} / \mathrm{d})$ & $301.6^{\mathrm{a}}$ & $328.4^{\mathrm{ab}}$ & $362.6^{\mathrm{b}}$ & $353.4^{\mathrm{ab}}$ & 14.65 \\
\hline $\begin{array}{l}\text { EMNS } \\
\qquad \text { (g N/kg OMDR) }\end{array}$ & $21.0^{\mathrm{a}}$ & $23.4^{\mathrm{b}}$ & $23.5^{\mathrm{b}}$ & $22.4^{\mathrm{ab}}$ & 0.80 \\
\hline
\end{tabular}

SEM, standard error of the means; MNS, microbial nitrogen supply; MCP, microbial crude protein; EMNS, efficiency of microbial nitrogen synthesis; OMDR, digestible OM apparently fermented in the rumen.

${ }^{\text {ab }}$ Values in the same row with different superscripts differ $(p<0.05)$.

blood carried to the liver and converted to urea and it was excreted via urine N. According to Chen and Gomes (1995), $\mathrm{N}$ excretion and retention could reflect on differences in $\mathrm{N}$ metabolism because $\mathrm{N}$ retention was the most important index of the protein $\mathrm{N}$ status in ruminant. This also could be explained by the CT containing in the GPP and MPP. Nevertheless, the positive values for the retained $\mathrm{N}$ with supplementation of GPP and MPP rich in CT indicate that CT supplementation met the animals' needs for maintenance. On the other hand, Barry et al. (1986) observed that high CT content in Lotus pedunculatus increased faecal nitrogen excretion and decreased urinary nitrogen excretion, leading to higher overall nitrogen retention by sheep. Waghorn et al. (1987) suggested that increased nitrogen retention with Lotus corniculatus appeared to be due to improved utilization of absorbed nitrogen. Indeed, it has been suggested that CT might increase the efficiency of urea recycled to the rumen because $\mathrm{CT}$ reduce the rate of protein degradation and deamination in the rumen and therefore lower ruminal $\mathrm{NH}_{3}$. The results revealed that allantoin excretion and absorption were higher in the group of steers fed with GPP and MPP $(p<0.05)$. Furthermore, microbial nitrogen supply and microbial CP were significantly improved $(p<0.05)$ when steers were fed with GPP while efficiency of microbial nitrogen synthesis was significantiy higher in the GPP and monensin supplemented group $(p<0.05)$. Urinary excretion of PD is considered to be an indicator of microbial production in the rumen. 


\section{CONCLUSION}

Based on this study it could be concluded that GPP has potential as an alternative feed supplement in the concentrate diet that can result in improved rumen fermentation efficiency, digestibility, propionic acid concentration and microbial protein synthesis. In addition, GPP could reduce acetic to propionic ratio and protozoal population. Therefore, supplementation of GPP in ruminant feeding is recommended. Interestingly, GPP showed comparable results as using monensin or MPP.

\section{CONFLICT OF INTEREST}

We certify that there is no conflict of interest with any financial organization regarding the material discussed in the manuscript.

\section{ACKNOWLEDGMENTS}

The authors would like to express their most sincere thanks to the Tropical Feed Resources Research and Development Center (TROFREC), Thailand Research Fund (TRF) through the Royal Golden Jubilee Ph.D. Program, Department of Animal Science, Faculty of Agriculture, Khon Kaen University and Agricultural Development Research Center of Northeast Thailand and PB Valley Khao Yai Winery, Thailand for their kind financial support and experimental facilitie.

\section{REFERENCES}

Anantasook, N., M. Wanapat, and A. Cherdthong. 2014. Manipulation of ruminal fermentation and methane production by supplementation of rain tree pod meal containing tannins and saponins in growing dairy steers. J. Anim. Physiol. Anim. Nutr. 98:50-55.

AOAC. 1998. Official Methods of Analysis. 2, 16th edn. AOAC, Arlington, VA, USA.

Appuhamy, J. A. D. R. N., A. B. Strathe, S. Jayasundara, C. Wagner-Riddle, J. Dijkstra, J. France, and E. Kebreab. 2013. Anti-methanogenic effects of monensin in dairy and beef cattle: A meta-analysis. J. Dairy Sci. 96:5161-5173.

Barry, T. N., T. R. Manley, and S. J. Duncan. 1986. The role of condensed tannins in the nutritional value of Lotus peduculatus for sheep (4. Sites of carbohydrate and protein digestion as influenced by dietary reactive tannin concentration). Br. J. Nutr. 55:123-137.

Bhatta, R., S. Mani, L. Saruah, L. Baruah, and K. T. Sampath. 2012. Phenolic composition, fermentation profile, protozoa population and methane production from sheanut (Butryospermum Parkii) byproducts in vitro. Asian Australas. J. Anim. Sci. 25:1389-1394.

Chen, X. B. and M. J. Gomes. 1995. Estimation of microbial protein supply to sheep and cattle based on urinary excretion of purine derivatives-an overview of the technical details
(Occasional publication). International Feed Resources Unit, Rowett Research Institute, Aberdeen, UK.

Crocker, C. L. 1967. Rapid determination of urea nitrogen in serum or plasma without deproteinization. Am. J. Med. Technol. 33:361-365.

Foiklang, S., M. Wanapat, and T. Norrapoke. 2016. In vitro rumen fermentation and digestibility of buffaloes as influenced by grape pomace powder and urea treated rice straw supplementation. Anim. Sci. J. 87:370-377.

Galyean, M. L. 1989. Laboratory Procedures in Animal Nutrition Research. Texas Tech University, Lubbock, USA.

Gemeda, B. S. and A. Hassen. 2015. Effect of tannin and species variation on in vitro digestibility, gas, and methane production of tropical browse plants. Asian Australas. J. Anim. Sci. 28:188-199.

Guan, H., K. M. Wittenberg, K. H. Ominski, and D. O. Krause. 2006. Efficacy of ionophores in cattle diets for mitigation of enteric methane. J. Anim. Sci. 84:1896-1906.

Hungate, R. E. 1969. A role tube method for cultivation of strict anaerobes. In: Methods in Microbiology (Eds. J. R. Norris and D. W. Ribbons). Academic Press Inc., NY, USA. pp. 117-132.

Jayanegara, A., E. Wina, and J. Takahashi. 2014. Meta-analysis on methane mitigating properties of saponin-rich sources in the rumen: Influence of addition levels and plant sources. Asian Australas. J. Anim. Sci. 27:1426-1435.

Krause, D. O. and J. B. Russell. 1996. An rRNA approach for assessing the role of obligate amino acid-fermenting bacteria in ruminal amino acid deamination. Appl. Environ. Microbiol. 62:815-821.

Lee, S. S., J. K. Ha, and K. J. Cheng. 2000. Relative contributions of bacteria, protozoa, and fungi to in vitro degradation of orchard grass cell walls and their interactions. Appl. Environ. Microbiol. 66:3807-3813.

Makkar, H. P. S. 2003. Effects and fate of tannins in ruminant animals, adaptation to tannins, and strategies to overcome detrimental effect of feeding tannin-rich feeds. Small Rumin. Res. 49:241-256.

McAllister, T. A. and C. J. Newbold. 2008. Redirecting rumen fermentation to reduce methanogenesis. Aust. J. Exp. Agric. 48:7-13.

McSweeney, C. S., B. Palmer, D. M. McNeill, and D. O. Krause. 2001. Microbial interactions with tannins: Nutritional consequences for ruminants. Anim. Feed Sci. Technol. 91:8393.

Moate, P. J., S. R. O. Williams, V. A. Torok, M. C. Hannah, B. E. Ribaux, M. H. Tavendale, R. J. Eckard, J. L. Jacobs, M. J. Auldist, and W. J. Wales. 2014. Grape marc reduces methane emissions when fed to dairy cows. J. Dairy Sci. 97:5073-5087.

Norrapoke, T., M. Wanapat, S. Wanapat, and S. Foiklang. 2014. Effect of Centella Asiatica powder (CAP) and Mangosteen peel powder (MPP) on rumen fermentation and microbial population in swamp buffaloes. J. Anim. Plant Sci. 24:435-444.

Pilajun, R. and M. Wanapat. 2013. Microbial population in the rumen of swamp buffalo (Bubalus bubalis) as influenced by coconut oil and mangosteen peel supplementation. J. Anim. Physiol. Anim. Nutr. 97:439-445.

Poungchompu, O., M. Wanapat, C. Wachirapakorn, S. Wanapat, and A. Cherdthong. 2009. Manipulation of ruminal fermentation and methane production by dietary saponins and 
tannins from mangosteen peel and soapberry fruit. Arch. Anim. Nutri. 63:389-400.

Mathew, S., S. Sagatheman, J. Thomas, and G. Mathen. 1997. An HPLC method for estimation of volatile fatty acids of ruminal fluid. Indian J. Anim. Sci. 67:805-807.

SAS. 1998. User's Guide: Statistics, Version 6. 12th edn. SAS. Inst. Inc., Cary, NC, USA.

Van Soest, P. J., J. B. Robertson, and B. A. Lewis. 1991. Methods for dietary fiber, neutral detergent fiber, and non-starch polysaccharides in relation to animal nutrition. J. Dairy Sci. 74:3583-3597.

Waghorn, G. C., M. J. Ulyatt, A. John, and M. T. Fisher. 1987. The effect of condensed tannins on the site of digestion of amino acids and other nutrients in sheep fed on Lotus corniculatus L. Br. J. Nutr. 57:115-126.
Wanapat, M. 1990. Nutritional Aspects of Ruminant Production in Southeast Asia with Special Reference to Thailand. Dept. of Animal Science, Faculty of Agriculture, Khon Kaen University, Khon Kaen, Thailand. 217 p.

Wanapat, M. and O. Pimpa. 1999. Effect of ruminal $\mathrm{NH}_{3}-\mathrm{N}$ levels ruminal fermentation, purine derivatives, digestibility and rice straw intake in swamp buffaloes. Asian Australas. J. Anim. Sci. 12:904-907.

Wanapat, M., P. Kongmun, O. Poungchompu, A. Cherdthong, P. Khejornsart, R. Pilajun, and S. Kaenpakdee. 2012. Effects of plants containing secondary compounds and plant oils on rumen fermentation and ecology. Trop. Anim. Health Prod. 44:399-405.

Yu, J. and M. Ahmedna. 2013. Functional components of grape pomace: Their composition, biological properties and potential applications. Int. J. Food Sci. Technol. 48:221-237. 